www.volsu.ru

DOI: https://doi.org/10.15688/jvolsu11.2018.2.11

UDC 577.24

LBC 28.703

\title{
MOLECULAR MECHANISMS OF OXIDATIVE STRESS IN AGING
}

\author{
Olga V. Kal'dinova \\ Volgograd State University, Volgograd, Russian Federation \\ Inna A. Desyatirkina \\ Volgograd State University, Volgograd, Russian Federation \\ Galina A. Sroslova \\ Volgograd State University, Volgograd, Russian Federation \\ Yuliya A. Zimina \\ Volgograd State University, Volgograd, Russian Federation
}

\begin{abstract}
The paper presents a brief overview of the problems in studying the aging under the influence of oxidative reactions in the Human body. The features of the free radical theory of aging were analyzed, the role of antioxidant enzymes was considered. Aging is a complex of processes and phenomena occurring in the Human body under the influence of various factors, the oxidative metabolism has an important role in this process. The study of the mechanisms of aging opens up the prospect of using this knowledge to find methods to prolong human life.

Key words: aging, oxidative stress, oxidative reactions, human body, antioxidant protection.
\end{abstract}

УДК 577.24

\section{МОЛЕКУЛЯРНЫЕ МЕХАНИЗМЫ ОКИСЛИТЕЛЬНОГО СТРЕССА ПРИ СТАРЕНИИ}

\section{Ольга Викторовна Кальдинова}

Волгоградский государственный университет, г. Волгоград, Российская Федерация

Инна Александровна Десятиркина

Волгоградский государственный университет, г. Волгоград, Российская Федерация

Галина Алексеевна Срослова

Волгоградский государственный университет, г. Волгоград, Российская Федерация

\section{Юлия Александровна Зимина}

Волгоградский государственный университет, г. Волгоград, Российская Федерация

\footnotetext{
Аннотация. Работа представляет краткий обзор проблем изучения процессов старения под воздействием окислительных реакций в организме. Проанализированы особенности свободнорадикальной теории старения, рассмотрена роль ферментов антиоксидантной защиты. Старение представляет собой комплекс процессов и явлений, происходящих в организме человека под воздействием различных факторов, важную роль играет окислительный метаболизм. Изучение механизмов старения открывает перспективу использования этих знаний для поиска методов, позволяющих продлить жизнь человека.

Ключевые слова: старение, окислительный стресс, окислительные реакции, организм человека, антиоксидантная защита.
} 


\section{МАТЕРИАЛЫ КОНФЕРЕНЦИИ}

Механизмы, регулирующие старение человека, зависят от различных факторов, которые в настоящее время изучены недостаточно полно. Очевидно, это связано с несовершенными методами изучение данной проблемы, связанные с вопросами биоэтики при проведении экспериментов над людьми, а результаты изучения процессов старения на животных, имеющих непродолжительный период жизни сложно экстраполировать на человека.

В последнее время разработка новых молекулярных методов позволила выявить основные пути старения. Изучение механизмов старения открывает перспективу использования этих знаний для поиска методов, позволяющих продлить жизнь человека. В данной работе представлен краткий обзор, посвященный процессу старения под воздействием окислительных реакций в организме.

Теория свободного радикала предполагает, что увеличение кислорода митохондриями с возрастом приводит к увеличению клеточного повреждения. Действительно, исследования показали, что потребление кислорода митохондриями аэробных организмов может произвести несколько активных радикалов, таких как супероксид, перекись водорода, и, возможно, гидроксильного радикала. Кроме того, митохондриями также вырабатывается оксид азота (NO), что может являться причиной процесса старения и некоторых заболеваний, связанных со старением. Было также установлено, что активированные полиморфно-ядерные нейтрофилы человека превращают нитрит в метаболиты $\mathrm{NO}_{2} \mathrm{Cl}$ и $\mathrm{NO}_{2}$, что может существенно способствовать образованию потенциально вредных соединений, таких как различные оксиданты и свободные радикалы. Аэробные организмы защищены от окислительных процессов сложной системой антиоксидантной защиты [2]. Эти факты явились основой свободнорадикальной теории старения.

Основное положение свободнорадикальной теории старения было сформулировано в 1954 г. Д. Харман, предположившим, что универсальной причиной старения служит свободнорадикальное окисление липидов, жиров и белков всех организмов кислородом воздуха [1]. В дальнейшем было выполнено значительное число самых разнообразных работ в этой области, но каких-либо однозначно интерпретируемых результатов получено не было. Так, митохондрии (основной потребитель кислорода клеток) старых животных не отличались значимо от таковых молодых по генерации супероксидного радикала, хотя отмечена структурная и функциональная неоднородность митохондрий старых животных, приводящая к значительным разбросам в результатах исследований и тенденция к повышению генерации АФК митохондриями старых животных все же, имеет место [6].

Аналогично, микросомы - другой значимый источник супероксидных радикалов, в старости генерируют в два раза меньшие количества АФК, снижение же активности супероксиддисмутазы (СОД) цитоплазмы происходит всего на $40 \%$, что явно компенсирует эти изменения. В отдельных случаях активность СОД тканей может даже повышаться с возрастом [2]. Активность ферментов антиоксидантной защиты, в принципе, зависит от нейроэндокринной регуляции и может, таким образом, подтверждать не теорию повреждений, а регуляторную теорию старения [3].

В то же время, с возрастом безусловно повышается содержание в тканях человека и животных продуктов окислительного повреждения макромолекул, в том числе ДНК. Это указывает на снижение скорости метаболизма для организма в целом. Повреждения ДНК, однако, могут играть важную роль в мутагенезе в старости [5].

Сейчас все больше склоняются к мнению, что наиболее значимым при старении оказывается усиленное перекисное окисление белков, а не липидов, чему способствует снижение активности СОД как результата снижения общей продукции АФК [2]. Общий анализ данных об участии АФК в процессах старения и сопровождающих старение заболеваний позволяет ряду авторов утверждать, что повреждение под действием АФК макромолекул приводит к мутациям, нестабильности генома в целом и развитию ряда возрастных патологий: рака, сердечно-сосудистых заболеваний, возрастной иммунодепрессии, дисфункции мозга, катаракты и др. [3].

Данные, полученные на трансгенных дрозофилах с дополнительными копиями гена 
СОД и каталазы, показали увеличение средней и максимальной продолжительности жизни. Трансгенные мыши с избыточной экспрессией СОД, каталазы и глутатион-пероксидазы обладали повышенной резистентностью к оксидативному стрессу, при снижении же активности этих генов мыши имели признаки преждевременного старения [4].

Функционирование антиоксидантных механизмов в митохондриях приводит к генерации АФК. Здесь имеется собственная система подавления АФК. Это приводит к тому, что митохондрия обладает собственной антиоксидантной системой; однако, при повреждении митохондрии и, впоследствии, снижении концентраций глутатиона и $\mathrm{NADPH}$, эффективность ее антиоксидантной системы может снизиться.

Функционирование антиоксидантных механизмов в митохондриях проявляется, в частности, в подавлении АФК. Однако, снижение эффективности собственной антиоксидантной системы митохондрий может снижаться, при их повреждении и впоследствии снижения концентраций глутатиона и NADPH.

Таким образом, старение представляет собой комплекс процессов и явлений, происходящих в организме человека под воздействием различных факторов, среди ко- торых важную роль играет окислительный метаболизм. Дальнейшее изучение его механизмов необходимо для решения проблем, связанных с увеличением продолжительности жизни, улучшения здоровья населения, сохранения активности людей в пожилом возрасте.

\section{СПИСОК ЛИТЕРАТУРЫ}

1. Alcedo, J. The role of the nervous system in aging and longevity / J. Alcedo, T. Flatt, E. G. Pasyukova // Front. Genet. - 2013. - Vol. 4, № 124. - P. 4-10.

2. Candore, G. Immunogenetics, gender, and longevity/G. Candore, C. R. Balistreri, F. Listi [et. al.] // Ann. N. Y. Acad. Sci. - 2006. - Vol. 1089.

3. Moskalev, A. A. From theories of aging to antiaging interventions/A. A. Moskalev, E. G. Pasyukova //Front Genet.-2014. - Vol. 5. - P. 276.

4. Smith, E. D. Genome-wide identification of conserved longevity genes in yeast and worms / E. D. Smith, B. K. Kennedy, M. Kaeberlein // Mech Ageing Dev. - 2007. - Vol. 128, № 1. - P. 106-111.

5. Smith, E. D. Quantitative evidence for conserved longevity pathways between divergent eukaryotic species / E. D. Smith, M. Tsuchiya [et al.] // Genome Res. -2008. - Vol. 18, № 4. - P. 564-570.

6. Wright, A. A polygenic basis for late-onset disease / A. Wright, B. Charlesworth, I. Rudan [et al.] // Trends Genet. - 2003. - Vol. 19, № 2. - P. 97-106.

\section{Information about the Authors}

Olga V. Kal'dinova, Senior Student, Department of Bioengineering and Bioinformatics, Volgograd State University, Prosp. Universitetskiy, 100, 400062 Volgograd, Russian Federation, biobio@volsu.ru.

Inna A. Desyatirkina, Senior Student, Department of Bioengineering and Bioinformatics, Volgograd State University, Prosp. Universitetskiy, 100, 400062 Volgograd, Russian Federation, biobio@volsu.ru.

Galina A. Sroslova, Associate-Professor, Department of Bioengineering and Bioinformatics, Volgograd State University, Prosp. Universitetskiy, 100, 400062 Volgograd, Russian Federation, sroslova.galina@volsu.ru.

Yuliya A. Zimina, PhD in Chemistry, Associate-professor, Department of Bioengineering and Bioinformatics, Volgograd State University, Prosp. Universitetskiy, 100, 400062 Volgograd, Russian Federation, ziminaua@mail.ru.

\section{Информация об авторах}

Ольга Викторовна Кальдинова, студент кафедры биоинженерии и биоинформатики, Волгоградский государственный университет, просп. Университетский, 100, 400062 г. Волгоград, Российская Федерация, biobio@volsu.ru.

Инна Александровна Десятиркина, студент кафедры биоинженерии и биоинформатики, Волгоградский государственный университет, просп. Университетский, 100, 400062 г. Волгоград, Российская Федерация, biobio@volsu.ru. 


\section{МАТЕРИАЛЫ КОНФЕРЕНЦИИ}

Галина Алексеевна Срослова, доцент кафедры биоинженерии и биоинформатики, Волгоградский государственный университет, просп. Университетский, 100, 400062 г. Волгоград, Российская Федерация, sroslova.galina@volsu.ru.

Юлия Александровна Зимина, доцент кафедры биоинженерии и биоинформатики, Волгоградский государственный университет, просп. Университетский, 100, 400062 г. Волгоград, Российская Федерация, ziminaua@mail.ru. 